University of Nebraska - Lincoln

DigitalCommons@University of Nebraska - Lincoln

Faculty Publications from the Harold W. Manter Laboratory of Parasitology

6-1-2008

\title{
A Review of Species in the Genus Rhopalias (Rudolphi, 1819)
}

Terry R. Haverkost

University of Nebraska - Lincoln, haverkost@gmail.com

Scott Lyell Gardner

University of Nebraska - Lincoln, slg@unl.edu

Follow this and additional works at: https://digitalcommons.unl.edu/parasitologyfacpubs

Part of the Parasitology Commons, and the Zoology Commons

Haverkost, Terry R. and Gardner, Scott Lyell, "A Review of Species in the Genus Rhopalias (Rudolphi, 1819)" (2008). Faculty Publications from the Harold W. Manter Laboratory of Parasitology. 32. https://digitalcommons.unl.edu/parasitologyfacpubs/32

This Article is brought to you for free and open access by the Parasitology, Harold W. Manter Laboratory of at DigitalCommons@University of Nebraska - Lincoln. It has been accepted for inclusion in Faculty Publications from the Harold W. Manter Laboratory of Parasitology by an authorized administrator of DigitalCommons@University of Nebraska - Lincoln. 


\title{
A REVIEW OF SPECIES IN THE GENUS RHOPALIAS (RUDOLPHI, 1819)
}

\author{
Terry R. Haverkost and Scott L. Gardner \\ The Harold W. Manter Laboratory of Parasitology, University of Nebraska State Museum, Lincoln, Nebraska 68588-0514. e-mail: slg@unl.edu
}

\begin{abstract}
Currently, there are 6 recognized species in the genus Rhopalias. These parasites are found in the small intestines of numerous species of marsupials throughout North and South America. Small mistakes in various classical taxonomic works have given rise to recent and numerous misidentifications of these species. In this work, we examine a total of 99 specimens across all species from museum collections in an attempt to determine informative taxonomic characters to distinguish these species. Despite confusion in the literature, accurate identification of these species can be achieved by observing the presence or absence of oral and flanking spines anterior to the oral sucker.
\end{abstract}

Species of Rhopalias (Trematoda: Rhopalidae) occur in the small intestines of marsupials throughout the Nearctic and Neotropical regions. Six species are currently recognized as valid. Rudolphi (1819) described Distoma coronatum from Didelphis marsupialis Linnaeus, 1758 collected by Johann Natterer in Brazil. Diesing (1850) described Rhopalophorus horridus from Chironectes minimus (Zimmermann, 1780) also collected by Natterer. Stiles and Hassall (1898) recognized that Rhopalophorus was an occupied name, and renamed the genus Rhopalias. Braun (1901) provided formal descriptions of both previously described species, and recognized and described another species, Rhopalias baculifer, from the same material examined by Diesing (1850). Chandler (1932) described Rhopalias macracanthus from North America in Didelphis virginiana Kerr, 1792. Kifune and Uyema (1982) described Rhopalias caballeroi from D. marsupialis and Philander opossum (Linnaeus, $1758)$ in Brazil. Finally, Rivallis et al. (2004) described the most recent species in this genus, Rhopalias caucensis from $P$. opossum collected in Colombia.

Skrjabin (1948) reproduced the descriptions of the species in the genus and provided an identification key to the known species of Rhopalias in that work, it is apparent that the labels for the figures referring to $R$. baculifer and $R$. horridus were reversed. Travassos et al. (1969) reproduced the work of Skrjabin (1948), along with the mislabeled figures. In the summary work of Yamaguti (1971), Figure 1651 of Rhopalias coronatus is a reproduction of $R$. horridus after Caballero (1946); this figure is in fact a representation of the currently recognized species $R$. caballeroi. In the same work (Yamaguti, 1971), Figure 1650B of $R$. coronatus, after Caballero (1946), but attributed to Braun (1901), also appears to be a drawing of $R$. caballeroi, but because the tentacles are covering the area where flanking spines would be found, identification to species is not possible from the Figure (although it is likely $R$. caballeroi). Finally, Radev et al. (2005) offer original figures of $R$. macracanthus drawn from specimens stored in the Manter Laboratory of Parasitology (HWML 0844, 22422, 22423). These specimens have been verified by 1 of us (T.R.H.) as $R$. macracanthus, but the figures of these specimens in Radev et al. (2005) lack the defining flanking spines, making them easily mistaken for $R$. $\mathrm{Ca}$ balleroi.

The species of Rhopalias are some of the most distinctive and easily recognized trematodes of mammals. However, the

Received 16 August 2007; revised 22 October 2007; accepted 25 October 2007 correct identification of the species in this genus has remained a difficult task, given the flaws in the above references and the lack of a thorough investigation of important taxonomic characters. Here, we intend to provide the most thorough investigation, to our knowledge, of the 6 currently recognized species in this genus.

\section{MATERIALS AND METHODS}

Specimens prepared and studied by us were stained in acetic Semichon's carmine, dehydrated in an ethanol series, cleared in terpineol and xylene, and mounted in Canada balsam or gum Damar (Prichard and Kruse, 1982). All other specimens studied were obtained from museum collections including: the United States National Parasite Collection (USNPC), Beltsville, Maryland; the Harold W. Manter Laboratory of Parasitology (HWML), Lincoln, Nebraska; the Naturhistorische Museum Wein (NMW), Vienna, Austria; the Universidad Nacional Autónoma de México (UNAM), Mexico City, Mexico; the Museo de Historia Natural at the Universidad Nacional Mayor de San Marcos (UNMSM), Lima, Peru; and the Kyushu University Museum (FUK), Fukuoka, Japan. Due to the commonality of misidentified and mislabeled specimens throughout the previous literature and in museum holdings, this paper deals only with specimens that have been studied by the authors. We do not include a comparative table of measurements from previous studies for this same reason. All measurements were taken with a Zeiss Ultraphot microscope equipped with an ocular micrometer and are presented to the nearest micrometer unless otherwise noted; ranges are followed by the mean and the number of characters studied (n) is given if different from the number of specimens studied (N). Canonical discriminant analysis (CDA) was performed on the natural $\log$ transformations of the 23 measurements summarized in Tables I and II excluding egg length and egg width using PROC CANDISC in SAS (version 6.12, SAS Institute, Cary, North Carolina).

\section{RESULTS}

\section{Specimens examined}

Rhopalias coronatus (22 specimens total): HWML34950 (1 specimen) from Didelphis albiventris, Paraguay; HWML70000 (12 vouchers) from P. opossum, Santa Cruz Department, Bolivia; HWML70002 (1 specimen) from P. opossum, Santa Cruz, Department, Bolivia; HWML70009 (3 vouchers) from P. opossum, Santa Cruz, Bolivia; HWML70013 (1 specimen) from $\mathrm{Lu}$ treolina crassicaudata Berisso, Argentina; UNAM4081 (1 specimen) from Didelphis sp., Veracruz, Mexico; USNPC14998 (1 specimen) from unknown host, Panama; USNPC72792 (2 vouchers) from D. marsupialis, El Tacal, Venezuela.

Rhopalias horridus: V4677 (1 neotype, 1 voucher) from $C$. minimus, Brazil.

Rhopalias caucensis (4 specimens total): UNAM1225 (2 specimens) from Didelphis mesamericana, Guazacapa, Guate- 
TABLE I. Measurements of Rhopalias species including $R$. coronatus, $R$. baculifer, and $R$. horridus by coefficient of variation (CV), distance from the anterior extreme to the anterior margin of the vitellaria (ANTVIT), and distance from the anterior margin of the vitellaria to the posterior margin of the acetabulum (ACEVIT).*

\begin{tabular}{|c|c|c|c|c|c|c|c|c|c|c|c|c|}
\hline Character & $n$ & Mean & Range & $\mathrm{CV}$ & $n$ & Mean & Range & $\mathrm{CV}$ & $n$ & Mean & Range & $\mathrm{CV}$ \\
\hline Total width & 22 & 735 & $219-1,584$ & 51 & 8 & 998 & $840-1,162$ & 12 & 2 & 489 & $422-556$ & 19 \\
\hline \multicolumn{13}{|l|}{ Acetabulum } \\
\hline Length & 22 & 376 & $150-840$ & 38 & 8 & 478 & $406-575$ & 14 & 2 & 157 & $143-170$ & 12 \\
\hline Length & 22 & 183 & $93-344$ & 37 & 8 & 275 & $190-356$ & 20 & 2 & 86 & 74-99 & 20 \\
\hline Width & 22 & 180 & $88-325$ & 37 & 8 & 249 & $230-331$ & 41 & 2 & 92 & $86-99$ & 10 \\
\hline \multicolumn{13}{|l|}{ Cirrus sac } \\
\hline Length & 22 & 970 & $563-2,219$ & 42 & 8 & 981 & $813-1,290$ & 17 & 2 & 668 & $573-762$ & 20 \\
\hline Width & 20 & 203 & $119-500$ & 51 & 8 & 271 & $200-344$ & 16 & 2 & 148 & $134-161$ & 13 \\
\hline \multicolumn{13}{|c|}{ Posterior testis } \\
\hline Length & 21 & 499 & $256-919$ & 39 & 8 & 1,416 & $888-1,848$ & 24 & 2 & 246 & $233-260$ & 8 \\
\hline Width & 21 & 149 & $75-281$ & 34 & 8 & 243 & $164-312$ & 20 & 2 & 130 & $125-134$ & 5 \\
\hline \multicolumn{13}{|l|}{ Ovary } \\
\hline Length & 21 & 169 & $75-344$ & 44 & 8 & 302 & 181-394 & 25 & 2 & 96 & $94-99$ & 3 \\
\hline Width & 20 & 178 & $88-350$ & 41 & 7 & 285 & $206-350$ & 20 & 2 & 99 & 94-103 & 6 \\
\hline \multicolumn{13}{|l|}{ Tentacle sac } \\
\hline Length & 21 & 693 & $375-1,188$ & 38 & 8 & 269 & $210-319$ & 18 & 2 & 311 & $305-318$ & 3 \\
\hline Width & 21 & 137 & $63-238$ & 35 & 8 & 104 & $63-150$ & 30 & 2 & 81 & 63-99 & 31 \\
\hline \multicolumn{13}{|l|}{ Prepharynx } \\
\hline Length & 22 & 39 & $0-313$ & 231 & 8 & 20 & $0-70$ & 153 & 2 & 56 & $54-59$ & 6 \\
\hline Egg number & 22 & 24 & $0-75$ & 87 & 8 & $>200$ & $>200$ & 0 & 2 & 53 & $35-70$ & 47 \\
\hline \multicolumn{13}{|l|}{ Eggs } \\
\hline Length & 94 & 90 & $70-108$ & 9 & 36 & 84 & $68-98$ & 8 & 10 & 68 & $65-72$ & 3 \\
\hline Width & 94 & 51 & $38-70$ & 12 & 36 & 52 & $38-63$ & 10 & 10 & 43 & $38-48$ & 7 \\
\hline
\end{tabular}

$* \mathrm{~N}$; total number of specimens; $n$; number of measurements. All data is rounded to the nearest $\mu \mathrm{m}$.

mala; UNAM966 (1 specimen) from D. marsupialis, San Jose, Costa Rica; USNPC92122 (1 specimen) from P. opossum, Colombia.

Rhopalias baculifer (8 specimens total): HWML35933 (2 specimens) from C. minimus, Panama; HWML70012 (4 specimens) from $P$. opossum, Catemaco, Mexico; UNAM1137 (2 specimens) from $P$. opossum Alajuela, Costa Rica.

Rhopalias macracanthus (25 specimens total): HWML22664 (1 specimen) from D. virginiana, Tallahasee, Florida; HWML70001 (2 specimens) from $P$. opossum, Santa Cruz Department, Bolivia; HWML70028 (1 specimen) from P. opos- sum, Santa Cruz, Bolivia; HWML70003 (1 specimen) from $P$. opossum, Santa Cruz, Department, Bolivia; HWML70010 (1 specimen) from $P$. opossum, Santa Cruz Department, Bolivia; UNAM1226 (6 specimens) from D. mesamericana, Chiapas, Mexico; UNAM2956 (1 specimen) from D. virginiana, Veracruz, Mexico; UNAM2957 (1 specimen) from D. virginiana, Veracruz, Mexico; UNAM4622 (1 specimen) from $D$. virginiana, Veracruz, Mexico; UNAM4625 (1 specimen) from $D$. virginiana, Veracruz, Mexico; UNAM968 (4 specimens) from D. marsupialis, Colima, Mexico; UNAM4081 (1 specimen) from Didelphis sp; USNPC5745 (1 specimen) from $D$. virginiana, Washington, 
TABLE II. Measurements of Rhopalias species including R. caballeroi, R. caucensis, and R. macracanthus by coefficient of variation (CV), distance from the anterior extreme to the anterior margin of the vitellaria (ANTVIT), and distance from the anterior margin of the vitellaria to the posterior margin of the acetabulum (ACEVIT).*

\begin{tabular}{|c|c|c|c|c|c|c|c|c|c|c|c|c|}
\hline Character & $n$ & Mean & Range & $\mathrm{CV}$ & $n$ & Mean & Range & $\mathrm{CV}$ & $n$ & Mean & Range & $\mathrm{CV}$ \\
\hline Total width & 37 & 691 & $313-1,074$ & 38 & 4 & 725 & 576-799 & 14 & 25 & 966 & $360-1,508$ & 33 \\
\hline \multicolumn{13}{|l|}{ Acetabulum } \\
\hline Length & 37 & 228 & 24-319 & 29 & 4 & 264 & $210-335$ & 21 & 25 & 359 & $155-538$ & 28 \\
\hline Length & 36 & 132 & $60-256$ & 28 & 4 & 154 & $125-185$ & 18 & 25 & 168 & $88-242$ & 28 \\
\hline Width & 36 & 135 & $75-288$ & 31 & 4 & 147 & $118-175$ & 20 & 25 & 185 & $70-264$ & 32 \\
\hline \multicolumn{13}{|l|}{ Cirrus sac } \\
\hline Length & 36 & 532 & $170-938$ & 32 & 3 & 685 & $575-775$ & 15 & 24 & 1,232 & $375-2,300$ & 35 \\
\hline Width & 34 & 141 & $53-225$ & 33 & 3 & 193 & $170-219$ & 13 & 23 & 257 & $75-375$ & 30 \\
\hline \multicolumn{13}{|c|}{ Posterior testis } \\
\hline Length & 37 & 401 & $70-582$ & 38 & 4 & 308 & $220-388$ & 23 & 23 & 523 & $123-806$ & 42 \\
\hline Width & 37 & 253 & $75-448$ & 51 & 4 & 222 & $94-275$ & 39 & 23 & 275 & $70-430$ & 33 \\
\hline \multicolumn{13}{|l|}{ Ovary } \\
\hline Length & 37 & 129 & $50-219$ & 31 & 4 & 140 & $100-160$ & 19 & 25 & 188 & $88-282$ & 34 \\
\hline Width & 37 & 146 & $68-233$ & 29 & 4 & 199 & $150-240$ & 22 & 25 & 213 & $85-300$ & 32 \\
\hline \multicolumn{13}{|l|}{ Tentacle sac } \\
\hline Length & 36 & 251 & $138-358$ & 21 & 3 & 293 & $275-320$ & 8 & 25 & 308 & $150-415$ & 28 \\
\hline Width & 36 & 94 & $38-184$ & 33 & 3 & 123 & $113-140$ & 12 & 25 & 139 & 45-190 & 30 \\
\hline \multicolumn{13}{|l|}{ Prepharynx } \\
\hline Length & 36 & 42 & $0-105$ & 78 & 4 & 46 & $0-125$ & 130 & 25 & 92 & $0-314$ & 86 \\
\hline Egg number & 37 & 8 & 0-90 & 208 & 4 & 7 & $0-17$ & 109 & 25 & 22 & $0-101$ & 141 \\
\hline \multicolumn{13}{|l|}{ Eggs } \\
\hline Length & 68 & 82 & $53-105$ & 11 & 4 & 95 & $92-98$ & 3 & 67 & 98 & $75-113$ & 7 \\
\hline Width & 68 & 45 & $32-60$ & 16 & 4 & 49 & $44-52$ & 7 & 67 & 55 & $36-74$ & 13 \\
\hline
\end{tabular}

$* \mathrm{~N}$; total number of specimens; $n$; number of measurements. All data is rounded to the nearest $\mu \mathrm{m}$.

DC; USNPC69744 (2 specimens) from D. virginiana, Florida; USNPC75092 (1 specimen) from D. virginiana, Leon County, Florida; USNPC8548 (1 specimen) (paratype) from D. virginiana, Houston, Texas.

Rhopalias caballeroi (37 specimens total): FUK264-1 (1 specimen), FUK311 (9 specimens), FUK584 (2 specimens) (paratypes) from D. marsupialis, Huanuco, Peru; HWML70021 (8 specimens) from P. opossum, Santa Cruz Department, Bolivia; HWML35933 (3 specimens) from C. minimus, Panama; UNMSM1076 (5 specimens) (paratopotypes) from $P$. opossum, Huanuco, Peru; UNMSM1077 (1 specimen) (paratopotype) from D. marsupialis, Huanuco, Peru; HWML70014 (1 specimen) from L. crassicaudata, Berisso, Argentina; UNAM4081 (1 specimen) from Didelphis sp., Veracruz, Mexico; UNAM965 (1 specimen) from D. marsupialis, Venezuela; USNPC92124 (5 specimens) from $P$. opossum, Colombia.

\section{Description with translation-original from Lamothe-Argumedo (1979)}

Original description: Rhopalias (Diesing, 1850) Stiles and Hassall, 1898. 
Trematoda con cuerpo alargado, espinoso; la porción anterior excavada ventralmente más amplia que la posterior y con un par de trompas retráctiles armadas con ganchos. Ventosa oral subterminal, con prefaringe, faringe musculosa y esófago; ciegos largos llegando al extremo posterior del cuerpo. Acetábulo mayor que la ventosa oral, cerca del extremo anterior. Testículos de forma variable situados en el tercio medio del cuerpo o más posteriormente, uno atrás del otro; bolsa del cirro larga, clavifome, extendiéndose posteriormente al acetábulo y conteniendo un complejo prostático bien desarrollado. Poro genital medio preacetabular. Con un agujero glandular preacetabular en forma de copa que se abre inmediatamente abajo del poro genital. Ovario esférico, medio, postacetabular y pretesticular; no existe un receptáculo seminal, útero largo o corto, en el campo intercecal, entre el ovario y el poro genital. Vitelógenas foliculares, dispuestas en los campos laterales que pueden o no confluir en el espacio pretesticular, desde el borde posterior del acetábulo hasta el extremo posterior del cuerpo. Parásitos intestinales de marsupiales, ocasionalmente de otros animales. Diagnosis genérica, con los caracteres de la familia. Especie tipo: Rhopalias coronatus (Rudolphi, 1819) Stiles y Hassall, 1898.

Translation: Trematodes with a long, thorny body; forebody concave, wider than posterior part and with a pair of armed retractile tentacles with hooks. Subterminal oral sucker, with prepharynx, muscular pharynx, and esophagus; long ceca extending to the posterior end of body. Acetabulum larger than oral sucker, near anterior end. Testicles of variable shape located at midbody, in tandem; cirrus pouch long, claviform, extending beyond the acetabulum and containing a well-developed prostate complex. Genital pore preacetabular at midbody or midline with a glandular preacetabular hole that opens immediately behind the genital pore. Ovary spherical, located at midbody, postacetabular and pretesticular; without seminal receptacle, uterus in intercecal field between ovary and genital pore. Vitteline follicles, arranged in lateral fields may or may not come close together in pretesticular space, from posterior edge of the acetabulum to posterior end of body. Intestinal parasites of marsupials, occasionally of other animals. Generic diagnosis, with the characters of family. Type species: Rhopalias coronatus (Rudolphi, 1819) Stiles and Hassall, 1898.

\section{Remarks}

Although most accounts of species of Rhopalias mention the "oral spines," it is evident that most workers did not always distinguish between the 2 sets of spines present on some of the specimens. We recognize 2 separate sets of spines on the anterior of the body. One set, herein called the "oral spines," lies immediately anterior to the oral sucker. These spines are often arranged in 2 rows and 8-16 spines may be visible at any one time. The second set of spines, herein called the "flanking spines," are a paired set arranged laterally to the oral spines. The number of visible spines from each flanking set may number from 2 to 6 . Often, the flanking spines are contrasted from the oral spines by a small physical separation or by being in a different orientation after permanent mounting on a slide.

The presence of the ventral hood in these species can cause problems with various measurements by distorting the width of the specimen and the distance between the anterior extreme of the worm and the acetabulum. The ventral hood is usually more pronounced in larger specimens, and more likely to be prominent in $R$. coronatus than any of the other species.

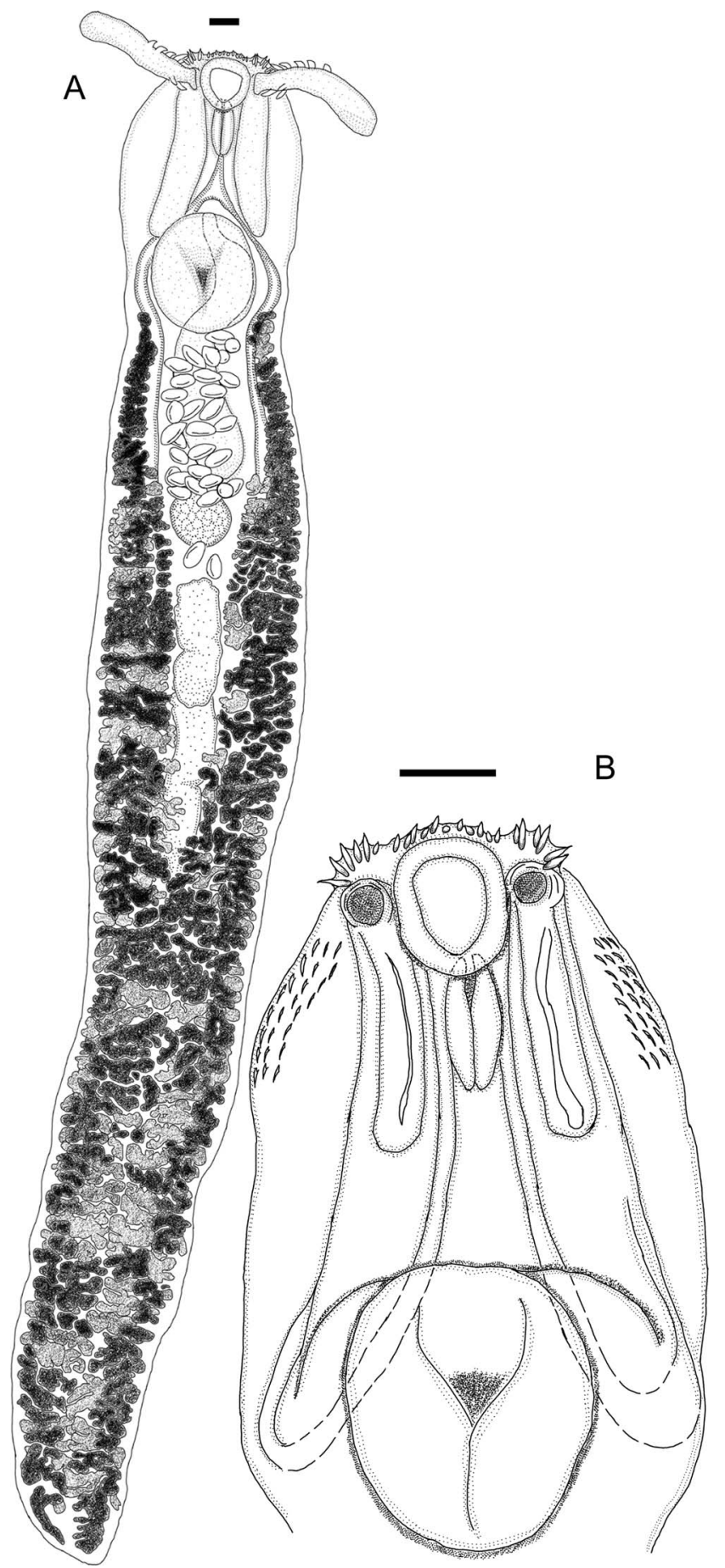

FIGURE 1. Rhopalias coronatus. (A) Entire specimen. (B) Anterior end. Both specimens are HWML70000. Both scale bars $=0.1 \mathrm{~mm}$.

\section{Rhopalias coronatus (Rudolphi, 1819) Stiles and Hassall, 1898}

(Fig. 1)

Synonyms: Rhopalias dobbini Prod'Hon 1968

Diagnosis: Flanking and oral spines present. Between 3 and 11 spines visible within tentacle sacs; spines measuring between 32 and 67 long (56). Size of spines on tentacles varies according to position of that spine on tentacle. Seen clearly on fully everted tentacle: proximal spines shorter than distal spines. Spines concentrated in proximal 


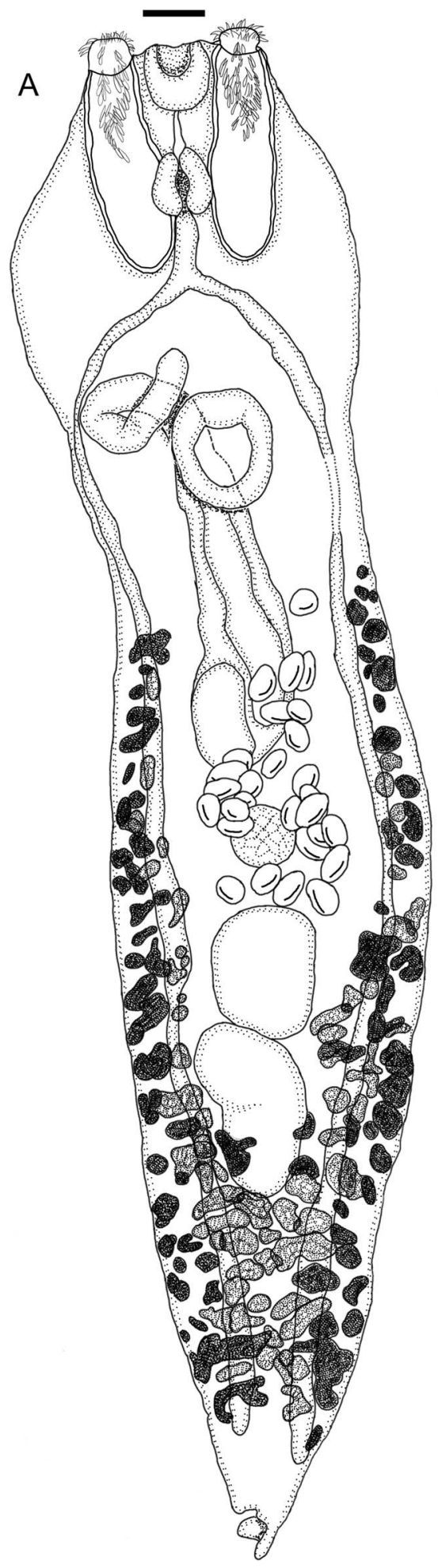

B

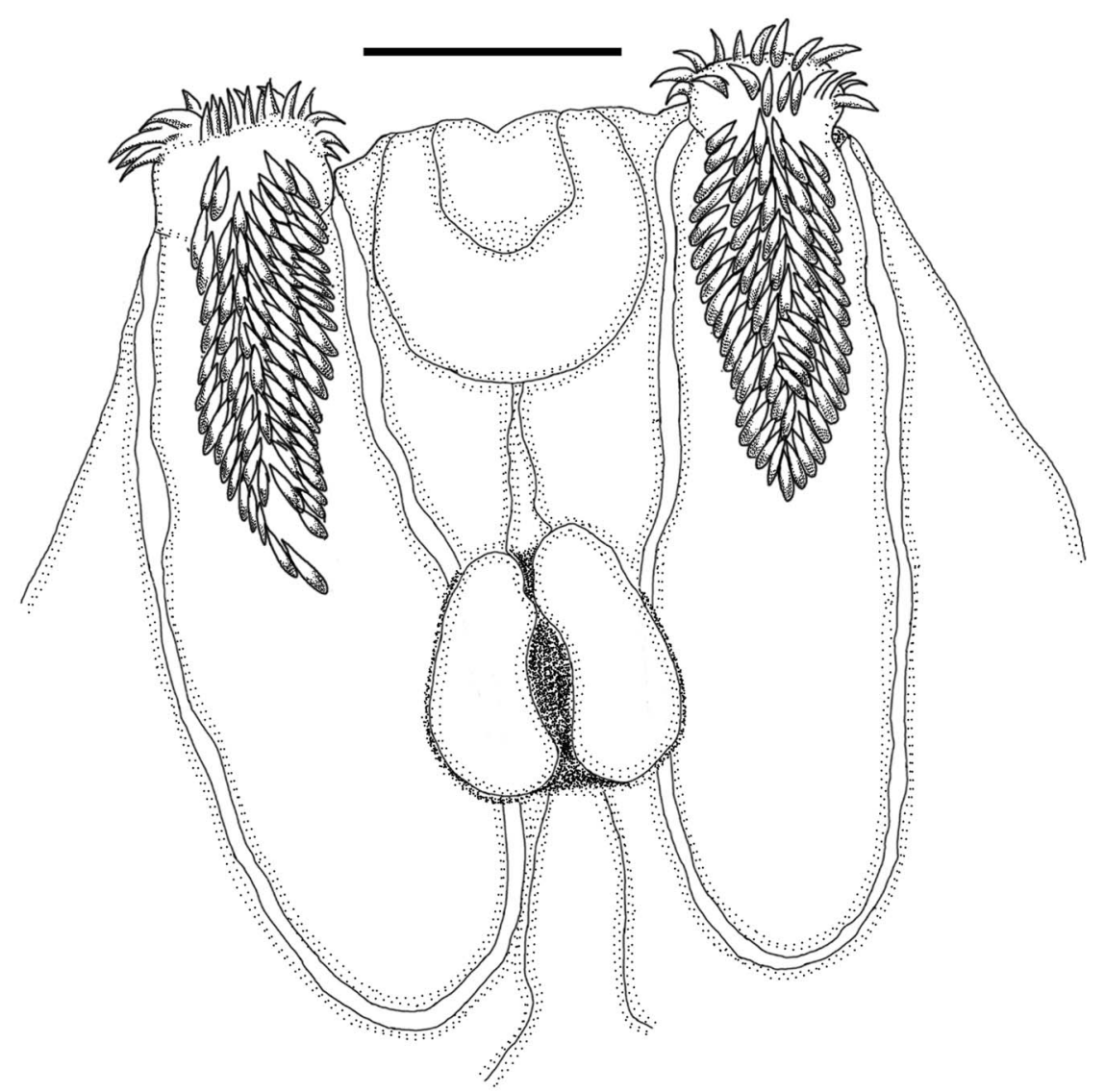

Figure 2. Rhopalias horridus. (A) Entire specimen. (B) Anterior end. Both specimens are NMW4677. Both scale bars $=0.1$ mm.

half of tentacle. Tentacle sacs very long, reaching far beyond posterior margin of pharynx. Tentacles may or may not reach acetabulum. Specimens 2,160-9,360 (4,440) long by 219-1,584 (735) wide. Acetabulum 150-840 (376) long by 150-816 (350) wide. Oral sucker 93-344 (183) long by 88-325 (180) wide. Cirrus sac 563-2,219 (970) long, terminating near ovary. Testes in tandem, usually overlap, anterior testis $156-625(333 ; \mathrm{n}=21)$ long by $100-281(167 ; \mathrm{n}=21)$ wide and posterior testis 256-919 (499; $\mathrm{n}=21)$ long by 75-281 (149; $\mathrm{n}$ $=21)$ wide. Ovary $75-344(169 ; \mathrm{n}=21)$ long by $88-350(178 ; \mathrm{n}=$ 20) wide. Prepharynx absent or present and up to 313 (39) long. Pharynx 115-425 (202) long by 30-244 (104; n = 21) wide. Esophagus absent or present and up to $606(186 ; n=20)$ long. Specimens with average of 24 eggs in uterus, eggs measure 70-108 $(90 ; n=84)$ long by $38-70(51 ; n=95)$ wide. 


\section{Remarks}

Rhopalias coronatus is easily distinguished from almost all other species mainly by the extent of the tentacle sacs. These tentacle sacs in $R$. coronatus extend far beyond the posterior margin of the pharynx, often, but not necessarily, to the acetabulum. Specimens of $R$. horridus share this feature, but these 2 species can be distinguished as the tentacular spines of $R$. horridus are clearly visible, small, and numerous, whereas those of $R$. coronatus are often hard to see, large, and number less than 10 spines per tentacle. Also, $R$. coronatus has both oral spines and flanking spines, where $R$. horridus has neither.

\section{Rhopalias horridus (Diesing, 1850) Stiles and Hassall, 1898 \\ (Fig. 2)}

Synonyms: Rhopalias goyanna Komma and Alves, 1974

Diagnosis: Flanking spines and oral spines absent. Tentacular spines small and numerous, measuring 25-30 (27) long. Tentacle sacs consistently reach 50 beyond posterior margin of pharynx. Tentacle sacs 305 318 (311) long by 63-99 (81) wide. Specimens from 2,434-2,492 $(2,463)$ in total length, 422-556 (489) in total width. Acetabulum 143170 (157) long by 143-184 (164) wide. Oral sucker 74-99 (86) long by 86-99 (92) wide. Cirrus sac 573-762 (668) long. Testes lie in tandem and overlap slightly, anterior testis 148-188 (168) long by 143-157 (150) wide, posterior testis 233-260 (246) long and 125-134 (130) wide. Ovary anterior to anteriormost testis, measures 94-99 (96) long by 94-103 (99) wide. Prepharynx always present, 54-59 (56) long. Pharynx 86-103 (94) long by 55-90 (72) wide. Esophagus always present, 85-170 (128) long. Worms average 53 eggs in uterus, eggs 65$72(68 ; \mathrm{n}=10)$ long by $38-48(43 ; \mathrm{n}=10)$ wide.

\section{Remarks}

Although this species has been reported numerous times from throughout South America, all specimens of $R$. horridus examined by us during this study were misidentifications. The only material available for study for this species comes from the specimens described by Braun (1901). Three vials of specimens were provided to us by the NMW in Vienna, Austria. Only 2 specimens prepared from these vials were identified as $R$. horridus. The rest of the specimens, as noted by Braun (1901), are $R$. coronatus.

There is no mention by Braun (1901) or by Gomes and Vicente (1972), of spines flanking the oral sucker in this species. However, the figures provided by Gomes and Vicente (1972) depicting this species clearly indicate the presence of flanking spines. This observation is repeated in their Table 1. Inspection by 1 of us (S.L.G.) of the specimens listed in the study by Gomes and Vicente (1972) revealed that these specimens were $R$. horridus and that no flanking spines were present.

Komma and Alves (1974) described R. goyanna from Didelphis azarae in Brazil. The specimens they describe are attenuated just posterior to the testes. These specimens are actually $R$. horridus that have been "pinched," which is a common condition in species of Rhopalias (see below for a more complete discussion). We believe the preoral spines the authors refer to in their description are not the oral spines as recognized in this work, but are actually body spines.

Diesing (1850) did not assign a holotype specimen for this species, and Braun (1901) did not assign any equivalent type specimen when he reviewed the material. Although no bottles as listed in Braun (1901) were found at the NMW in Vienna, material labeled as part of a collection by Natterer were found, and, after consultation with Dr. Helmut Sattmann, the curator of the NMW, we believe these specimens to be equivalent. From this lot, we name "V4677 e" as the neotype of the species.

Rhopalias horridus can be distinguished from other species of Rhopalias by the numerous small spines on the tentacles.

\section{Rhopalias caucensis Rivillas et al., 2004} (Fig. 3)

Diagnosis: Flanking spines and oral spines present. Tentacular spines large and few, average tentacle length from $85-138(113 ; \mathrm{n}=10)$. Between 8 and 10 spines observed from each tentacle. Tentacle sacs never reach beyond posterior margin of pharynx. Tentacle sacs $275-320(293 ; n=3)$ long by $113-140(123 ; \mathrm{n}=3)$ wide. Specimens $1,999-2,471(2,211)$ in total length and 576-799 (725) in total width. Acetabulum 210-335 (264) long and 194-290 (242) wide. Oral sucker 125-185 (154) long by 118175 (147) wide. Cirrus sac 575-775 (685; $\mathrm{n}=3$ ) long. Testes in tandem, do not necessarily overlap. Anterior testis 150-225 (196) long and 213360 (293) wide. Posterior testis 220-388 (308) long by 94-275 (222) wide. Ovary 100-160 (140) long by 150-240 (199) wide. Prepharynx absent or up to 125 (46). Pharynx 120-175 (149) long by 85-100 (92) wide. Esophagus never observed. Specimens average 7 eggs in uterus; eggs 92-98 (95) long by $44-52$ (49) wide.

\section{Remarks}

Rhopalias caucensis can be distinguished from other species of Rhopalias by possessing short tentacle sacs, i.e., not extending beyond the posterior margin of the pharynx, and the presence of both oral spines and flanking spines.

\section{Rhopalias baculifer Braun, 1901 (Fig. 4)}

Diagnosis: Flanking and oral spines absent. Between 8 and 10 spines visible within tentacle sacs, these spines large and few; average length from 50-120 (86; $\mathrm{n}=26)$. Tentacle sacs 210-319 (269) long by 63-150 (104) wide and never reach posterior margin of pharynx. Specimens 7,128$12,600(9,369)$ long and 840-1,162 (998) wide. Acetabulum 406-575 (478) long by 435-757 (508) wide. Oral sucker 190-356 (275) long, 230-331 (249) wide. Cirrus 813-1,290 (981) long and never reaches ovary. Testes lie in tandem, slightly overlap; anterior testis $720-1,488(1,188)$ long by $127-336$ (257) wide; posterior testis $888-1,848(1,416)$ long by $164-312$ (243) wide. Ovary 181-394 (302) long and 206-350 (285; n = 7) wide. Prepharynx absent or up to 70 (20). Pharynx 150-281 (215) in length by 104-200 (158) in width. Esophagus never observed in specimens studied. Always more than 200 eggs in uterus, eggs measuring 68-98 $(84 ; \mathrm{n}=36)$ long by $38-63(51 ; \mathrm{n}=36)$ wide.

\section{Remarks}

Rivallis et al. (2004) revise the species by describing a "short form" of $R$. baculifer. We believe these specimens represent $R$. caballeroi. The authors used Travassos et al. (1969) in their identification, and likely viewed only the figures. Rhopalias baculifer and $R$. caballeroi have no oral nor flanking spines, but these 2 species are easily distinguished by total length, as, from our measurements, the shortest specimen of $R$. bacuilfer $(7,128)$ is more than twice as long as the longest specimen of $R$. caballeroi $(3,489)$.

Rhopalias baculifer is by far the longest species in this group. It is easily distinguished from $R$. coronatus by the tentacle sacs, with these sacs in $R$. baculifer never reaching beyond the posterior margin of the pharynx. Also, the cirrus sac in R. bacuilfer is very short and does not reach the ovary, as in all other species.

\section{Rhopalias macracanthus Chandler, 1933} (Fig. 5)

Synonyms: Rhopalias louisiana Hearin, 1937

Diagnosis: Oral spines absent. Flanking spines present. Between 6 and 10 spines visible within tentacle sacs, spines $83-138(108 ; n=52)$ in length. Tentacle sacs 150-415 (308) long by 45-190 (139) wide, never reach beyond posterior margin of pharynx. Specimens 969-7,093 $(3,683)$ long and 360-1,508 (966) wide. Acetabulum 155-538 (359) long by $125-475$ (341) wide. Oral sucker 88-242 (168) long by $70-$ 264 (185) wide. Cirrus sac 375-2,300 $(1,232 ; \mathrm{n}=24)$ long, terminates close to ovary. Testes lie in tandem, may or may not overlap. Anterior testis 63-675 (346) long and 58-475 (286) wide; posterior testis $123-$ $806(523 ; \mathrm{n}=23)$ long and $70-430(275 ; \mathrm{n}=23)$ wide. Ovary $88_{-}$ 282 (188) long by 85-300 (213) wide. Prepharynx absent or up to 314 (92). Pharynx 70-230 (170) long by 50-205 (139) wide. Esophagus absent or up to 113 (43). Specimens averaged 22 eggs in uterus; eggs $75-113(98 ; \mathrm{n}=67)$ long by $36-74(55 ; \mathrm{n}=67)$ wide. 


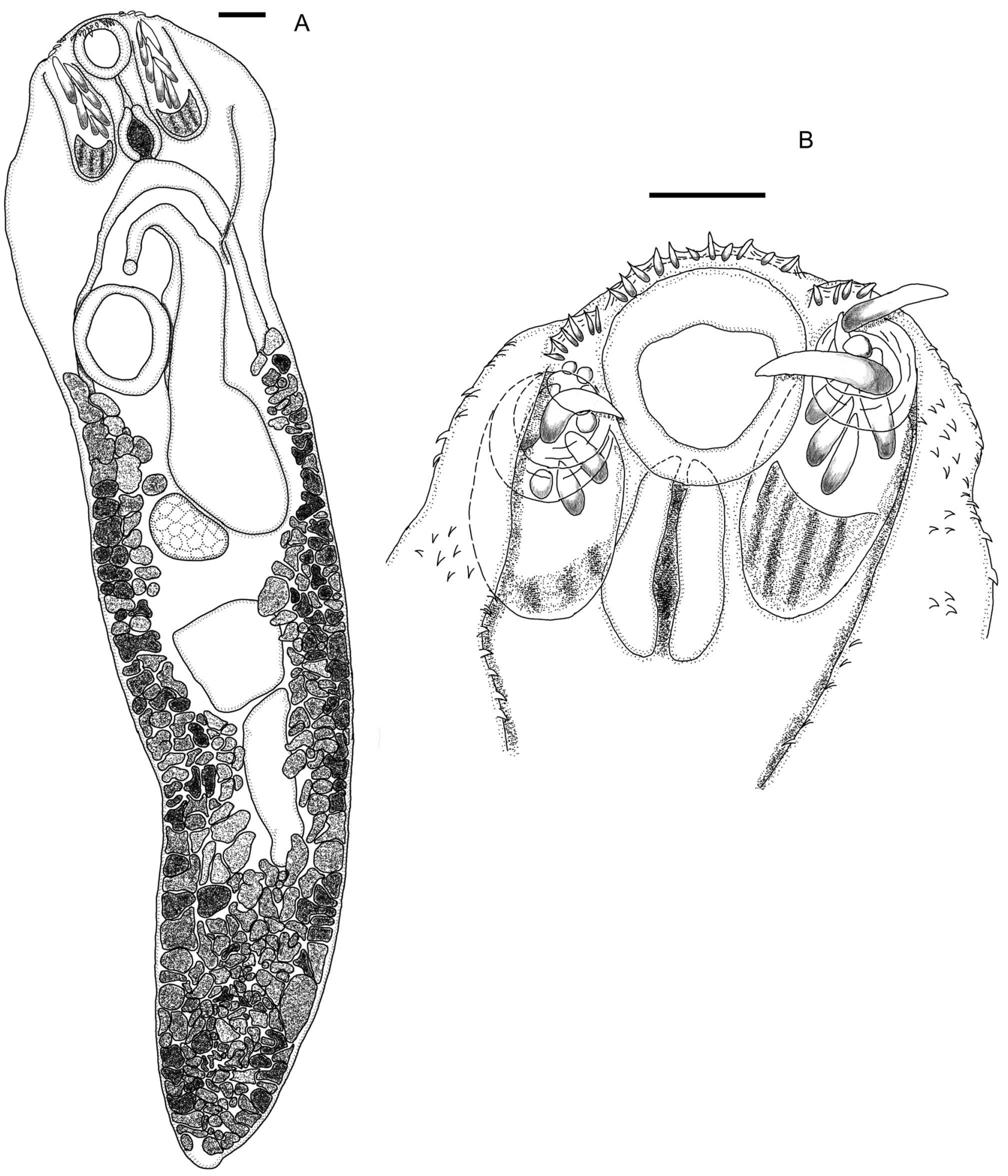

FIGURE 3. Rhopalias caucensis. (A) Entire specimen (USNPC92122). (B) Anterior end (UNAM1225). Both scale bars $=0.1 \mathrm{~mm}$.

\section{Remarks}

Rhopalias macracanthus can be distinguished from other species of Rhopalias by having tentacle sacs that do not extend beyond the posterior margin of the pharynx and by having only flanking spines.
Rhopalias caballeroi Kifune and Uyema, 1982

(Fig. 6)

Diagnosis: Oral and flanking spines absent. Between 4 and 11 spines visible within tentacle sacs, spines $48-131(93 ; \mathrm{n}=76)$ in length. Tentacle sacs $138-358(251 ; \mathrm{n}=36)$ long by $38-184(94 ; \mathrm{n}=36)$ wide, 


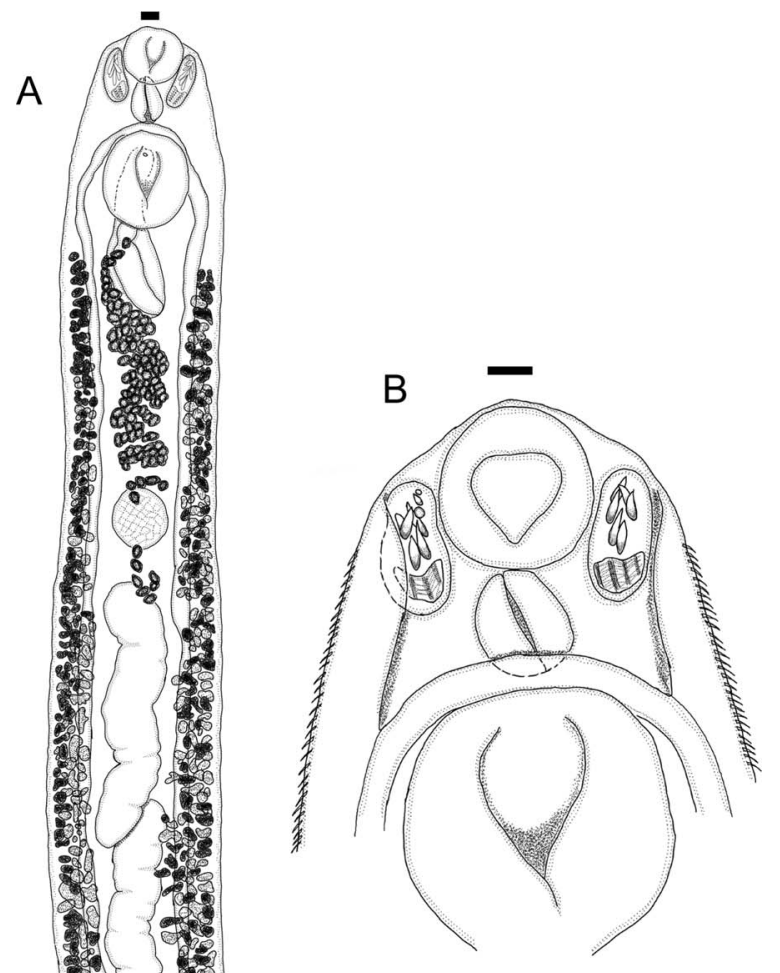

FIGURE 4. Rhopalias baculifer. (A) Entire specimen. (B) Anterior end. Both specimens are HWML70012. Both scale bars $=0.1 \mathrm{~mm}$.

never reach beyond posterior margin of pharynx. Specimens 813-3,489 $(2,287)$ long and 313-1,074 (695) wide. Acetabulum 138-319 (235) long by $138-340$ (244) wide. Oral sucker 60-256 (132 n = 36) long by $75-288(135 \mathrm{n}=37)$ wide. Cirrus sac $170-938(532 \mathrm{n}=36)$ long and terminates close to ovary. Testes lie in tandem, may or may not overlap. Anterior testis 33-488 (247) long, 113-515 (281) wide. Posterior testis 70-582 (401) long and 75-448 (253) wide. Ovary 50-219 (129) long by 68-233 (146) wide. Prepharynx absent or up to 105 (42; $\mathrm{n}=36)$. Pharynx $59-228(126 ; \mathrm{n}=36)$ long by $38-157(83 ; \mathrm{n}=36)$ wide. Esophagus absent or up to $114(16 ; \mathrm{n}=36)$. Specimens averaged 8 eggs in uterus, eggs $53-105(82 ; \mathrm{n}=68)$ long by $32-60(45 ; \mathrm{n}=$ 68) wide.

\section{Remarks}

We were able to obtain a majority of the type series for examination and found that the specimens had neither flanking nor oral spines. Kifune and Uyema (1982) remark that these spines are "usually" absent. Rivallis et al. (2004) recently collected this species from Colombia, but misidentified it as $R$. baculifer.

Because there has been much confusion in the literature in identification of the species of Rhopalias, we provide a key to the species.

\section{Key to the species of Rhopalias}

1a. Tentacle spines small, numerous $(>30)$ : oral and flanking spines absent .................. Rorridus

1b. Tentacles spines few $(<15)$, large: oral and flanking spines present or absent ................. 2

2a. Tentacle sacs extending far beyond posterior margin of pharynx $\ldots \ldots \ldots \ldots \ldots \ldots \ldots \ldots \ldots \ldots \ldots \ldots \ldots$ coronatus

2b. Tentacles not extending beyond posterior margin of pharynx

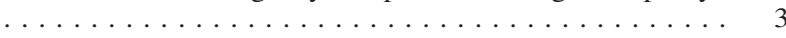

3a. Oral and flanking spines both absent $\ldots \ldots \ldots \ldots \ldots \ldots 4$

$3 b$. Some combination of oral and/or flanking spines present ... 5

4a. Specimen exceeds $6 \mathrm{~mm}$ total length . . . . . . R . baculifer

4b. Specimen less than $6 \mathrm{~mm}$ total length $\ldots \ldots \ldots R$. caballeroi 5a. Both oral and flanking spines present . . . . . . R. caucensis 5 b. Oral spines absent, flanking spines present ... R. macracanthus

\section{DISCUSSION}

In their description of $R$. goyanna, Komma and Alves (1974) describe the body of the specimen as "pinched," with the specimen missing its body posterior to the testes. This phenomenon was seen by us in a random assortment of $R$. coronatus specimens in the HWML collection. Specimens were seen in various stages of this pinching, which seemed to leave the worm intact, because the specimens did not seem to be leaking fluids. In some specimens, the posterior ends of the body appear shriveled and not pinched, but we believe that both scenarios likely lead to the same conclusion of a truncated body. No single factor, e.g., intra- or interspecific cooccurrence or crowding in the intestines, seemed a commonality with the occurrence of the pinching; a potential source of a specimen's pinching was a trichostrongyloid nematode seen wrapped around the constricted area.

In the past, researchers studying Rhopalias species have used various (and often untested) characters to make taxonomic decisions. These characters include, but are likely not limited to, distribution of the body spines (Hearin, 1937), size of the tentacle spines (Prod'Hon, 1968), and relative position of the vitellaria (Miyazaki et al., 1978). We agree with Braun (1901) that it would be unwise to use body spines as a character in species discrimination, as the spines are fragile and are known to fall off during the processes of collecting, fixing, staining, or mounting the specimen (Braun, 1901). Length of spines on the tentacles is also not a good character for species discrimination, especially in $R$. coronatus, as the tentacle spine length in this species can vary widely in a single individual. Our analysis included 2 measurements where we recorded the distribution and anterior and posterior extents of the vitellaria, the distance from the anterior extremity of the body to the vitellaria, and the distance from the posterior margin of the acetabulum to the vitellaria. We include this measurement in Tables I and 


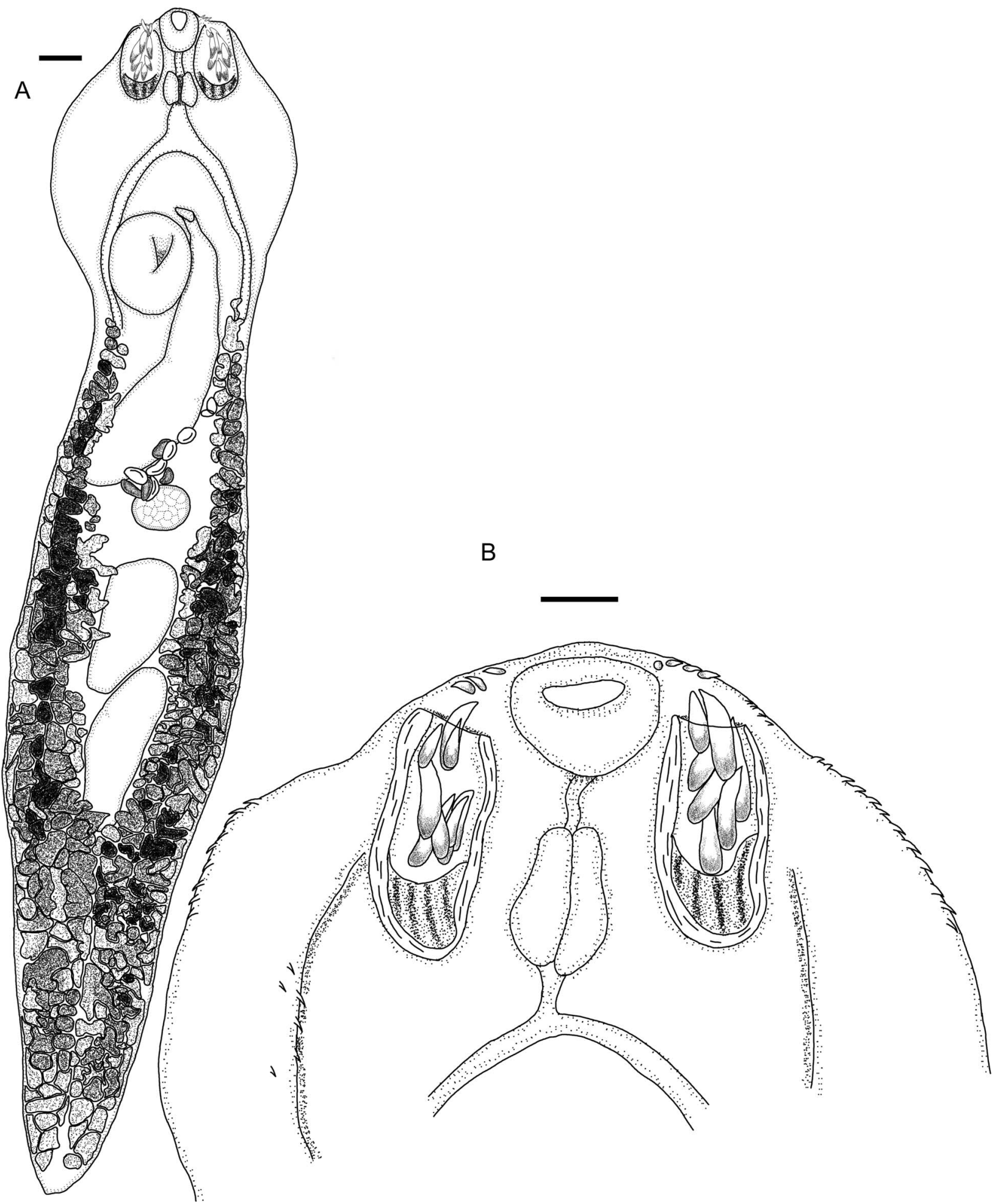

FIGURE 5. Rhopalias macracanthus. (A) Entire specimen (USNPC8547). (B) Anterior end (UNAM1226). Both scale bars $=0.1 \mathrm{~mm}$.

II and in the discriminant analysis to determine its potential in species separation.

In our analysis, proper discrimination of species was not achieved using any single quantitative character, but the results of the CDA (Fig. 7) showed that, using a linear combination of all characters, discrimination of species was possible. The first
CDA performed included all 6 species. The analysis provided good separation of $R$. coronatus and $R$. baculifer against an indiscriminant cluster of the other 4 species. While the analysis is interesting, little information is gained, as $R$. coronatus and $R$. baculifer are relatively easy to distinguish anyway and most of the confusion from past studies has involved misidentifica- 


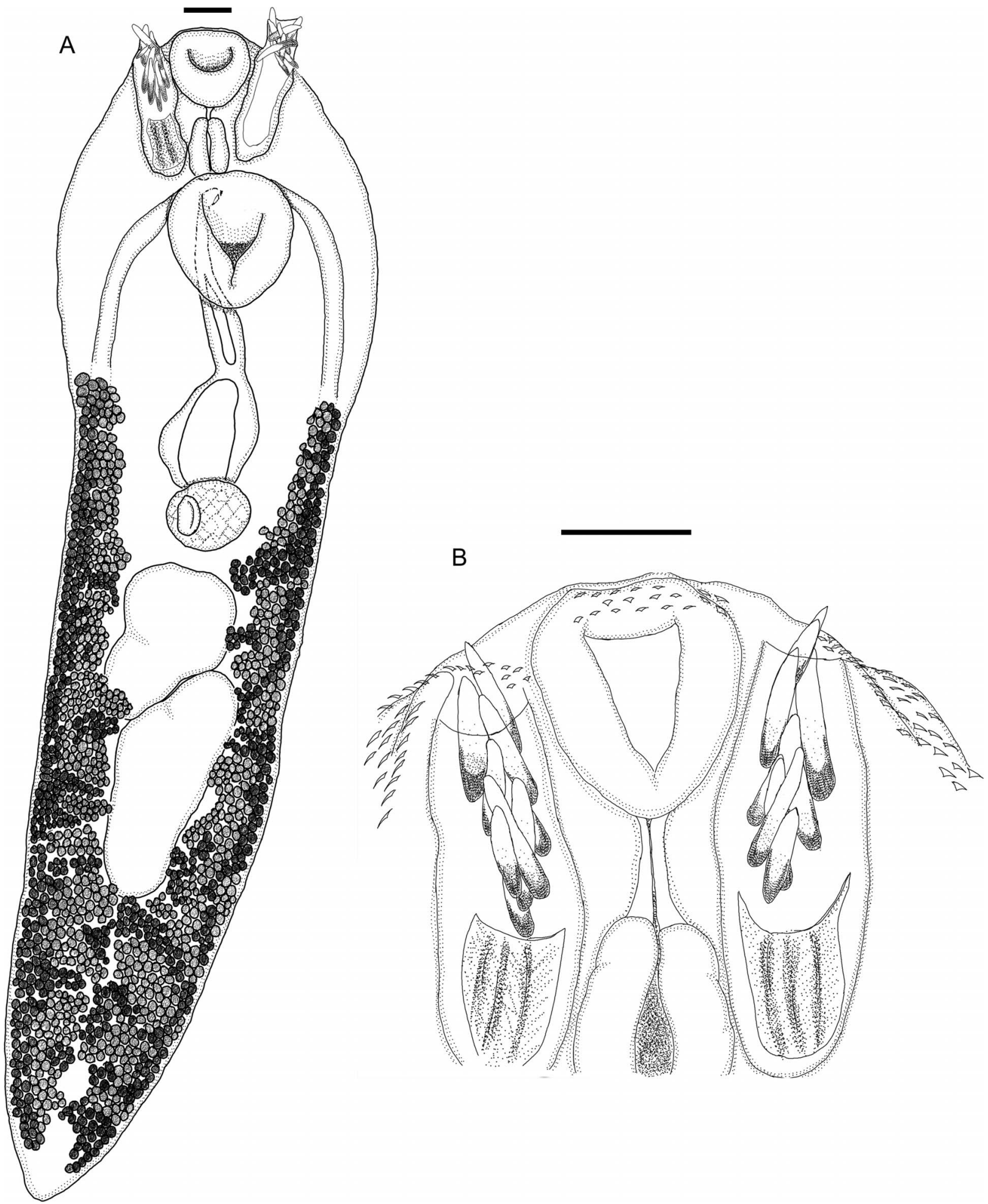

FigURE 6. Rhopalias caballeroi. (A) Entire specimen (FUK264-1). (B) Anterior end (UNMSM1076). Both scale bars $=0.1 \mathrm{~mm}$.

tions of the other 4 species. Thus, a second CDA was performed on only these 4 species. Based on the results of this analysis, the first 2 canonical variates were significant $(P<$ 0.001 ) and accounted for $89 \%$ of the variation in the analysis (see Table III). Each canonical variate is a linear combination of the independent variables (measurements), and each variate is independent of the other. Since the variate is a linear combination of each variable, the canonical loading associated with each variable can be interpreted as the relative contribution that variable has on each variate. Thus, it follows that cirrus length (CIRL), cirrus width (CIRW), pharynx width (PHW), and acetabulum length (ACEL) have the largest relative contribution 


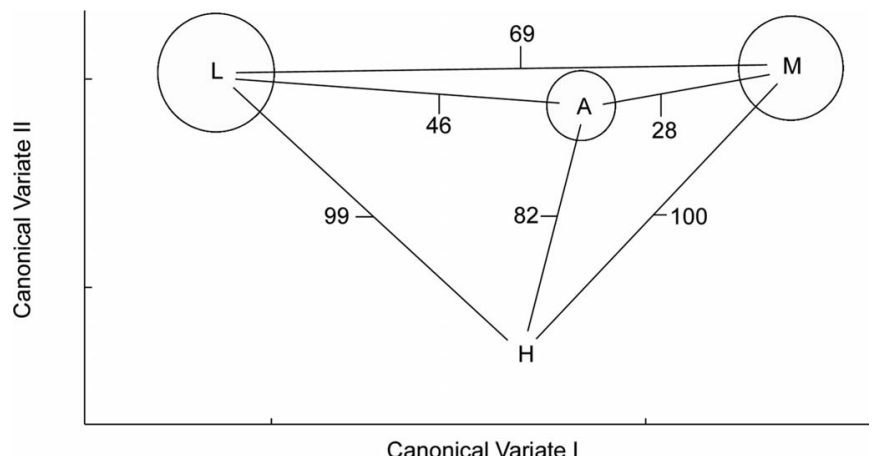

Canonical Variate I

FIGURE 7. Centroid plots of canonical variates I and II for 4 species of Rhopalias. Circles represent 1 standard deviation around the centroid. Relative euclidian distance between groups provided for each line connecting the centroids. $\mathrm{L}=R$. caballeroi, $\mathrm{A}=R$. caucensis, $\mathrm{M}=R$. macracanthus, $\mathrm{H}=R$. horridus.

to the first canonical variate, and thus species discrimination. The centroid values for the first 2 variates for each species were plotted (Fig. 7), along with a circle representing 1 standard deviation around each centroid. The graph clearly shows that the CDA supports the taxonomic separation of all species in this genus.

The observations and analyses herein show that the confusion with the identification of these species can be eliminated

TABLE III. The canonical discriminant loadings of the 23 independent variables for 2 canonical discriminant variates that distinguish 4 species of Rhopalias ( $R$. caucensis, $R$. horridus, $R$. caballeroi, $R$. macracanthus).

\begin{tabular}{lcc}
\hline & \multicolumn{2}{c}{ Canonical variate } \\
\cline { 2 - 3 } Variable & 1 & 2 \\
\hline LEN & 0.40 & 0.04 \\
WID & 0.38 & 0.22 \\
ACEL & 0.50 & 0.26 \\
ACEW & 0.43 & 0.33 \\
ORALL & 0.37 & 0.33 \\
ORALW & 0.39 & 0.29 \\
CIRL & 0.74 & 0.07 \\
CIRW & 0.66 & 0.10 \\
OVL & 0.43 & 0.22 \\
OVW & 0.45 & 0.27 \\
TES1L & 0.24 & 0.17 \\
TES1W & 0.02 & 0.20 \\
TES2L & 0.21 & 0.21 \\
TES2W & 0.14 & 0.25 \\
TENL & 0.34 & -0.11 \\
TENW & 0.48 & 0.16 \\
ANTVIT & 0.48 & -0.05 \\
ACEVIT & 0.15 & -0.34 \\
EGGNU & 0.20 & -0.25 \\
PHL & 0.43 & 0.23 \\
PHW & 0.53 & 0.16 \\
PREPHA & 0.16 & -0.05 \\
ESOLEN & 0.34 & -0.47 \\
VAR(\%) & 0.72 & 0.17 \\
$P$-value & 0.0001 & 0.0001 \\
\hline & &
\end{tabular}

when using taxonomically informative characters. However, with the wide variation in size exhibited by most of the species in this analysis, it would be beneficial to collect more specimens throughout the Neotropics and Nearctic to conduct an analysis on more temporally consistent specimens and determine if this variability can be attributed to geographic distance among populations.

\section{LITERATURE CITED}

Braun, M. V. 1901. Zur Kenntniss der Trematoden der Saugethiere. Zoologische Jahrbücher, Abteilung für Systematik 14: 311-348.

Caballero y C., E. 1946. Estudios helmintológicos de la región oncocercosa de México y de la República de Guatemala. Trematoda. II. Presencia de Paragonimus en reserorios naturales y descripción de un nuevo genéro. Anales del Instituto de Biologia, Universidad Nacional Autonoma de Mexico, Serie Zoologia 1 17: 137-165.

ChandLer, A. C. 1932. Notes on the helminth parasites of the opossum (Didelphis virginiana) in Southeast Texas, with descriptions of four new species. Proceedings of the U.S. National Museum 81: 1-15.

Diesing, C. M. 1850. Systema helminthum, Vindobonae, 588 p.

Gomes, D. C., AND J. J. Vicente. 1972. Estudo do genero Rhopalias Stiles \& Hassall, 1898 (Trematoda, Rhopaliasidae). Memorias do Instituto Oswaldo Cruz 70: 115-133.

HEARIN, J. T. 1937. A review of the genus Rhopalias Stiles and Hassell [sic], 1898 with a description of a new species from Didelphis virginiana pigra Bangs, 1989. M.S. Thesis. Louisiana State University, Baton Rouge, Louisiana, 79 p.

Kifune, T., AND N. Uyema. 1982. Report of the Fukuoka University Scientific Expedition to Peru, 1976. Part 3. Taxonomical studies on trematodes from marsupials and rodents with records of two crabs. Medical Bulletin of Fukuoka University 9: 241-256.

Komma, M. D., AND E. L. Alves. 1974. Rhopalias goyanna n.sp. (Trematoda, Rhopaliasidae) parastio de marsupial de Neropolis, Brasil. Revista de Patologia Tropical 3: 341-345.

Lamothe-Argumedo, R. 1979. Trematodos de mamiferos. 1. Redescripcion de Rhopalias macracnthus Chandler, 1932 y algunas consideraciones sobre el genero. Anales del Instituto de Biologia, Universidad Nacional Autonoma de Mexico, Serie Zoologia 1 49: 25-34.

Miyazaki, I., T. Kifune, S. Habe, AND N. Uyema. 1978. Reports of Fukuoka University scientific expedition to Peru, 1976. Occasional Publication, Department of Parasitology, School of Medicine, Fukuoka University, Japan 1: 1-28.

Prichard, M. H., AND G. O. W. KRUSE. 1982. The collection and preservation of animal parasites, University of Nebraska Press, Lincoln, Nebraska, $141 \mathrm{p}$.

ProD'Hon, P. J. 1968. Rhopalias dobbini n. sp., trématode parasite de Monodelphis domestica domestica. Bulletin du Muséum National D'Histoire Naturelle 2nd Série 40: 393-395.

Radev, V., S. L. GARdNer, AND I. KANEv. 2005. Family Rhopaliidae Looss, 1899. In Keys to the trematoda, A. Jones, R. A. Bray, and D. I. Gibson (eds.). CAB International and The Natural History Museum, London, U.K., p. 119-120.

Rivillas, C., E. Caro, H. Carvajal, and I. Vélez. 2004. Algunos trematodos digeneos (Rhopaliasidae, Opistorchiidae) de Philander opossum (Marsupialia) de la costa pacífica colombiana, incluyendo Rhopalias caucensis $\mathrm{n}$. sp. Revista de la Academia Colombiana de Ciencias Exactas, Físicas y Naturales XXVIII: 591-600.

RudOLPHI, C. A. 1819. Entozoorum synopsis cui accedunt mantissa duplex et indices loupletissimi. Sumptibus Augusti Rücker, Berlin, Germany, $811 \mathrm{p}$.

SkRJABIN, K. I. 1948. Trematodes of animals and man: Principles of trematodology. Akad Nauk, SSSR, Moscow, Russia, 600 p.

Stiles, C. W., AND A. Hassall. 1898. Notes on parasites, an inventory of the genera and subgenera of the trematode family Fasciolidae. Archives de Parasitologie 1: 81-99.

Travassos, L., J. F. Teixeira de Freitas, And A. Kohn. 1969. Trematódeos do Brasil. Memórias do Instituto Oswaldo Cruz 67: 1-886.

YAmaGuTi, S. 1971. Synopsis of digenic trematodes of vertebrates, Keigaku Publishing Co., Tokyo, Japan, 1074 p. 